\title{
ワイドバンドギャップ叛導体 発光デバイスの進展
}

藤田静雄

\section{半導体発光デバイスの 発明から応用へ}

1907年にイギリスのH. J. Round氏が、 SiC 結 晶に電圧を印加したときに発光することを発見 し1、これが発光ダイオード (LED) やレーザ ダイオード $(\mathrm{LD})$ へと続く研究開発の起源と 考えられている。その後、ソ連のO. V. Losev 氏は整流ダイオードからの発光を見出し、1927 年にはLEDとして論文発表している ${ }^{2}$ 。1954年 には直接遷移型半導体である GaAsバルク単結 晶の育成が始まり、また、エピタキシャル結 晶成長が盛んになり、1962年にアメリカのN. Holonyak Jr.氏が赤色LEDの開発に成功した ${ }^{3}$ 。 しかし、その外部量子効率は $0.01 \%$ と低く、実 用化に向けた一層の飛躍が必要であった。

当時の結晶成長技術は液相成長法であり、化 合物半導体の結晶成長における化学量論的組成 (ストイキオメトリ) を制御して、また、欠陥 の少ない高品質の結晶を得ることが困難であっ た。これに対し、1969年に蒸気圧制御温度差法 が東北大学の西澤潤一氏によって発案され、欠 陥の少ない高品質の化合物半導体結晶が得られ るようになり ${ }^{4,5}$ 、高輝度赤色および緑色 LED の実現をもたらした。これは商品化につなが り、スタンレー電気は 1976 年に $60 \mathrm{mcd}$ という 当時世界一の明るさを持つ「高輝度赤色 LED」 の連続製造技術の開発に成功し6、さらに1979
年に $\mathrm{GaP}$ 結晶を用いた「高輝度純緑色LED」 （80 mcd）を発表した。その後1984年には5000 mcd赤色 LED、 200 mcd 緑色 LED、 500 mcd黄 色LEDが開発されるに至り、LEDを用いたディ スプレイが実用化した。

LEDの開発は並行してLDの進展を生んだ。 1970年に米国ベル研究所の林厳雄氏、M. B. Panish氏、ソ連のZhores Alferov氏らが、ほ ぼ同時期に $\mathrm{AlGaAs} / \mathrm{GaAs}$ ダブルヘテロ接合構 造半導体LDの室温連続発振に成功した。そし て、1982年にはシャープ（株）がCDプレーヤ 用赤外LDを実用化し、プレーヤの生産が開始 された。 LDはまた光通信・光情報処理の基盤 デバイスで、1977年に東京工業大学の伊賀健一 氏が高出力化を可能とする “VCSEL”の提案 デバイス開発を行い、また、1982年には東京大 学の榊裕之氏、荒川泰彦氏らが量子ドットレー ザーを提案するなど、我が国が世界に先駆けた 貢献をなしている。

\section{ワイドギャップ半導体による 青色発光デバイスの開発}

赤色、緑色LEDの開発を受け、青色LEDの 開発が次の大きなターゲットとされたものの、 ここに大きな困難が待ち受けていた。青色発 光を実現しうる広いバンドギャップを持つ半 導体材料としては、SiC、GaN、II-VI族化合物 
（ZnSe、ZnSなど）が候補とされ、大きな期待 を受けた研究開発が行われた ${ }^{7}$ 。 $\mathrm{SiC}$ は古くか ら pn伝導性制御が可能で青色発光も見られて いたが、間接遷移型のバンド構造を持つこと が高輝度LEDへの応用に不利とされた。GaN と II-VI族化合物は直接遷移型であるが、大型 基板がないこと、原料の蒸気圧が高く欠陥が生 じやすいこと、 $\mathrm{p}$ 型伝導性制御が困難であるこ と、など克服すべき課題が多かった。II-VI族 化合物については、1983年には蒸気圧制御温 度差法により ZnSeのpn接合青色 LEDが示さ れ、また、GaAsや $\mathrm{GaP}$ 基板と格子整合するこ とから、分子線エピタキシ $(\mathrm{MBE})$ 等の制御 性に優れた結晶成長法によって平坦性に優れた 結晶層、量子井戸構造等が実現された。1990年 にMBEによる $\mathrm{p}$ 型ZnSeの実現、1991年に青緑 色LDの77Kパルス、その後連続発振、1993年 にLDの室温連続発振、といった成果が連続し、 多くの研究者の注目を受けることになった。し かし、その後デバイスの短寿命を克服すること ができず、また、1993年に GaNを用いた光度 1 Cdクラスの青色 LEDが商品化されたこともあ り、研究規模が急速に縮小した。

これに対し、GaNによる青色LEDは急速な 関心を集めるようになり、その基盤をなした新 規物理の発見、解明、創出が2014年のノーベ ル物理学賞につながったのである。図1に青色 LEDの基本構造を示す。これはバンドギャッ
プが青色に対応するInGaNに電子-正孔を閉じ 达めて高効率の発光を実現しょうとする、基本 的なダブルヘテロ (double hetero)構造である。 LEDを実現するために重要な要素技術として、 （i）サファイア基板上に結晶性が優れた $\mathrm{GaN}$ 層 を成長する技術、（ii） $\mathrm{p}$ 型層を得るためのドー ピング技術、（iii）高効率の発光を得るために 高品質 InGaN発光層を実現する技術、があげ られる。（i）については、AlNバッファ層を導 入するという赤㠃勇氏のアイデアを元に、低温 成長により天野浩氏がこれを実証したものであ る。（ii）については、天野氏がアクセプタドー ピングの実験中に、電子線励起によるアクセプ 夕の活性化を発見したことがきっかけと言われ ている。（iii）については、青色発光に寄与す

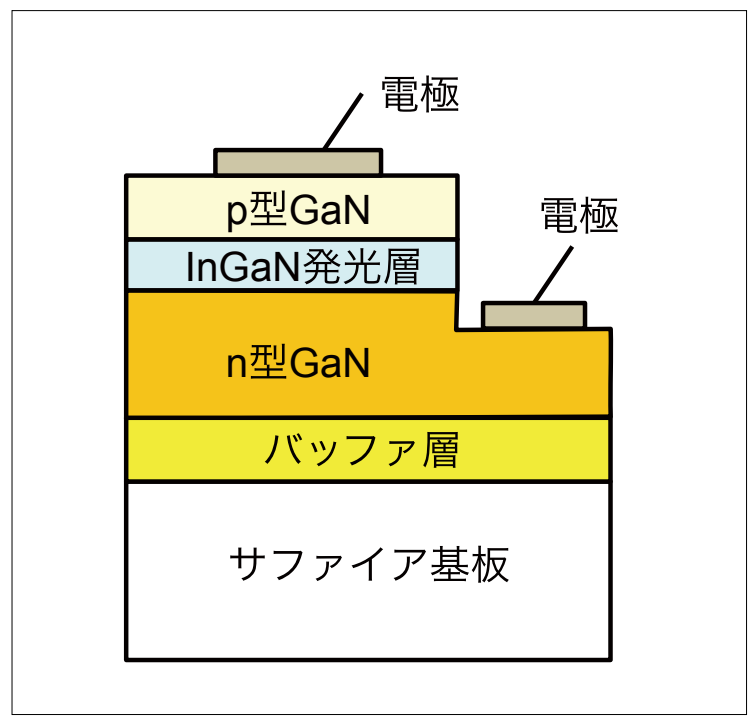

図 1 サファイア基板上GaNをベースにした青色 LEDの基本構造。 


\section{PROFILE}

藤田静雄 (ふじたしずお)

京都大学大学院工学研究科光 ·電子理工学教育研究

センター教授

専門 : 先進機能電子材料・プロセス・デバイス

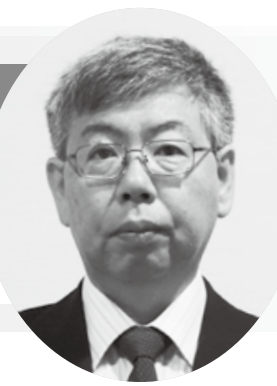

る高品質の InGaN発光層を、two-flow 成長法に よって実現可能という物理を発見した中村修二 氏の成果とされている。さらに中村氏は、将来 の商品化に効果的な技術として、（i）に対して $\mathrm{GaN}$ バッファ層を用い、（ii）に対して $\mathrm{N}_{2}$ 䨌囲 気中での熱処理を採用した。これらにより青色 LEDの実用的な生産プロセスが確立し、大量 生産への道が拓けることになった。

青色LEDをべースとして白色 LEDが実用化 されたことは、照明の革命を起こしたと言わ れる大きな波及効果をもたらした。ノーベル 物理学賞の受賞理由として“for the invention of efficient blue light-emitting diodes which has enabled bright and energy-saving white light sources”とされていることは、莫大な省エネ ルギーを達成した、地球への貢献を高く評価さ
れているためと言えよう。

\section{ワイドギャップ半導体 発光デバイスの今後}

$\mathrm{GaN}$ とInNの混晶である InGaN、あるいは AlN との混晶である $\mathrm{AlGaN}$ は、それぞれ $\mathrm{GaN}$ に比べて小さい、あるいは大きいバンドギャッ プを持つ。これにより紫外から赤外まで任意の 発光波長を持つLEDが実現できることが示唆 される。図 2 は各種LEDの発光波長と外部量子 効率の関係をまとめたものである ${ }^{8}$ 。 InGaN発 光層を用いた波長 $440 \mathrm{~nm}$ 付近のLEDが最も高 い発光効率を持つ一方で、緑色領域および紫外 領域において発光効率が低くなる。ここにはさ まざまな不明な物理や克服すべき課題が多く含 まれており、中村氏、 天野氏ともに「すべて の波長で効率 $100 \%$ の LEDを目指すことが 次の仕事」と語ってお られた。赤㠃氏、天野 氏は加圧下で結晶成長 を行う技術を開発し、 これにより高品質の結 晶を得ることが一つの 方法として研究を進め ておられる。また、高 
出力の白色LEDの実現にとっては、図1のよう にサファイア基板を用いて電流を横に流す構造 ではなく、導電性の $\mathrm{GaN}$ 基板を用いて電流を 縦に流す構造が望ましいが、大面積で高品質の GaN 基板が必要になる。中村氏と天野氏は、こ の基板の開発にも注力した研究を進めておられ る。このように、発光デバイスの今後の進展は さらに広範に広がることが予想される。

さらに、今回の三名の受賞者がなしえた成果 は、今後、照明に留まらない大きな波及効果に つながることに注目すべきである。青色 LED の開発は、半導体としての GaNのポテンシャル を明らかにした。そしてそれがいまやLEDに とどまらない波及効果をもたらすことが明らか になり、この分野の国際会議では 1,000 名以上 の参加者を集める広大な学術分野を形作ること になった。すなわち、GaNの応用分野は照明の 分野に留まらず、今後、電力制御のためのパワー デバイス、超高効率太陽電池、光触媒などへの 広がりを見せ、環境負荷の少ない社会の創成に 大きく寄与して行くと期待される。青色 LED を生み出した三氏の成果は、今後の地球のいの ちに貢献してゆくと言っても過言ではないであ ろう。

\section{参考文献}

[1] H. J. Round, Electrical World 49, 308 (1907).

[2] V. Losev, Telegrafi ya i Telefoniya bez Provodov 44, 485 (1927), cited in N. Zheludev, Nat. Photonics 1, 189 (2007).

[3] ゼネラル・エレクトリック・カンパニー, GE reports, 2012年8月15日.

[4] J. Nishizawa, Y. Okuno, and H. Tadano, J. Cryst. Growth 31, 215 (1975).

[5] J. Nishizawa, K. Suto, and T. Teshima, J. Appl. Phys. 48, 3484 (1977).

[6] 新技術開発事業団委託開発「発光ダイオードの連続製造 技術」1972年10月～1976年4月.

［7］藤田茂夫, 応用物理 54, 40 (1985).

[8] 藤田静雄, 応用物理 82, 836 (2013); 京都大学川上養一教 授の提供による. 